\title{
Per-Shipment Costs and the Lumpiness of International
}

\author{
Trade* \\ Cecília Hornok ${ }^{\dagger}$ and Miklós Koren ${ }^{\ddagger}$
}

January 2014

Astract Using detailed U.S. and Spanish export data, we document that trade costs of a per-shipment nature are associated with less frequent and larger shipments, i.e. more lumpiness, in international trade. This finding is pervasive across broad product categories, but most apparent for industrial supplies, parts and accessories and food products.

Keywords: lumpy trade, shipment, per-shipment cost

JEL code: F14

*Koren is grateful for the financial support from the "EFIGE" project funded by the European Commission's Seventh Framework Programme/Socio-economic Sciences and Humanities (FP7/2007-2013) under grant agreement no 225551. Hornok thanks for financial support from the Marie Curie Initial Training Network "GIST" funded by the European Commission's Seventh Framework Programme (project reference: 211429).

${ }^{\dagger}$ Centre for Economic and Regional Studies of the Hungarian Academy of Sciences (MTA KRTK). cecilia.hornok@gmail.com

${ }^{\ddagger}$ Central European University, MTA KRTK and CEPR. KorenM@ceu.hu 


\section{Introduction}

With the diminishing use of tariff-type trade restrictions, the focus of trade policy has been increasingly shifting towards less standard trade barriers. Some of these trade costs are not proportional to the value of trade and, hence, do not comply with the iceberg assumption of most trade models. This paper focuses on per-shipment costs, fixed costs that accrue per each shipment. Examples are the costs of filling in customs declarations and other forms, or having the cargo inspected by health and sanitary officials.

The starting point of our paper is a tradeoff between per-shipment trade costs and shipping frequency. In the presence of per-shipment costs, exporters would want to send fewer and larger shipments. However, an exporter waiting to fill a container before sending it off or choosing a slower transport mode to accommodate a larger shipment sacrifices timely delivery of goods and risks losing orders to other, more flexible (e.g., local) suppliers. Similarly, holding large inventories between shipment arrivals incurs substantial costs and prevents fast and flexible adjustment of product attributes to changing consumer tastes.

Using transaction-level export data from the U.S. and Spain, we explore the relationship between shipping frequency and shipment size on the one hand, and per-shipment costs on the other. We capture per-shipment trade barriers with indicators of the World Bank's Doing Business database on the time to import a standardized container shipment and the associated monetary costs. Our estimation results confirm that, within narrowly-defined product category and given a transport mode, both the U.S. and Spain exports fewer and larger shipments to countries with larger per-shipment costs.

From our product-specific estimates we conclude that the positive relationship between 
trade lumpiness and per-shipment costs is pervasive across broad product categories. Nevertheless, we find the most robust evidence for industrial supplies, parts and accessories and food products. Our tentative interpretation is that per-shipment costs are most disruptive for perishable products and the fragmented production chain.

Our emphasis on shipments as a fundamental unit of trade follows Armenter and Koren (forthcoming), who discuss the implications of the relatively low number of shipments on empirical models of the extensive margin of trade. We also relate to the literature that challenges the dominance of iceberg trade costs in trade theory, such as Hummels and Skiba (2004) and Irarrazabal, Moxnes and Opromolla (2010). They argue that a considerable part of trade costs are per-unit costs, which has important implications for trade theory. Per-unit trade costs do not necessarily leave the within-market relative prices and relative demand unaltered, hence, welfare costs of per-unit trade frictions can be larger than those of iceberg costs.

The importance of per-shipment trade costs or, in other words, fixed transaction costs has also been emphasized by Alessandria, Kaboski and Midrigan (2010). They argue that pershipment costs lead to the lumpiness of trade transactions: firms economize on these costs by shipping products infrequently and in large shipments and maintaining large inventory holdings. We consider our paper complementary to theirs in that we exploit the cross-country variation in per-shipment costs.

More recently, Kropf and Sauré (forthcoming) have inferred the magnitude of per-shipment trade costs based on the the size and the frequency of export transactions of Swiss firms and found these costs economically important. Here we take a different approach by using direct measures of per-shipment costs and bringing them to trade transactions data. 
Section 2 describes the database, measurement issues, and provides evidence for trade lumpiness. Section 3 presents the estimation results. Section 4 concludes.

\section{Data and measurement}

We describe the data for per-shipment trade barriers and transaction-level trade flows. Then we report evidence for trade lumpiness in the U.S. and Spain.

\subsection{Per-shipment trade barriers}

We capture per-shipment trade barriers with indicators of import costs from the World Bank's Doing Business survey. They are time-related and monetary costs of import documentation, customs clearance and inspection, port/terminal handling and transit from the port of arrival to the final destination. ${ }^{1}$ The survey is carried out every year among trade facilitators at large freight-forwarding companies. Questions refer to a standardized containerized cargo shipped by sea. ${ }^{2}$ The indicators are country-specific and do not vary with the trading partner or across products.

Per-shipment costs as measured by the Doing Business indicators are not negligible in

\footnotetext{
${ }^{1}$ Monetary costs include various fees and charges, but exclude customs tariffs, trade taxes or bribes.

${ }^{2}$ The traded product is assumed to travel in a dry-cargo, 20-foot, full container load via ocean. It weighs 10 tons, is valued at USD 20,000, is not hazardous and does not require special treatment or standards. (http://www.doingbusiness.org/MethodologySurveys/TradingAcrossBorders.aspx)
} 
magnitude. Reporting the 2009 survey results, Table 1 shows that the average time to import, which excludes port-to-port transportation, is close to one month, while monetary costs are $\$ 1,600$ for the average destination country. Monetary costs alone correspond to around 12 per cent of the value of a typical U.S. or Spanish shipment.

\section{[TABLE 1 HERE]}

Document preparation is the most time-consuming out of the four procedures. In terms of monetary costs, the transit from port is the most burdensome, which also represents the largest variability across destination countries. The time and the monetary cost measures are only moderately correlated with correlation coefficients of around $0.3-0.4$, except for the transit from port procedure with a correlation coefficient of 0.8 .

\subsection{Trade transactions and their lumpiness}

We examine disaggregated data on exports of the U.S. and Spain in 2009 to a large set of destination countries. We want to look at the lumpiness of trade transactions, i.e., how frequently the same good is exported to the same destination country within the year, as well as the typical size of a shipment.

This exercise requires transaction-level (shipment-level) trade data. Customs Bureaus in both the U.S. and Spain record trade flows at the shipment level. The Spanish database is made publicly available at this same level, whereas the U.S. database is somewhat aggregated up. An entry in the publicly available U.S. Foreign Trade statistics reported by the Census Bureau is differentiated by product, country of destination, month of shipment, and shipping Census region. Most importantly, the dataset also reports the number of shipments 
aggregated in each entry, so we can precisely measure the total number of shipments to a destination in a given product category. More than half of the entries contain only one shipment, and the average number of shipments per entry is 4.8. In both databases, the identity of the exporting firm is omitted for confidentiality reasons.

We consider 172 destination countries for the U.S. and 169 (144 non-EU) destinations for Spain. Product classification is very detailed in both cases (10-digit Schedule B in the U.S. and 8-digit Combined Nomenclature in the Spanish case). In the case of U.S. exports, which is not a shipment-level database, we can calculate the value of a shipment per each cell by dividing the trade value with the number of shipments in that cell. Similarly, physical shipment size is trade quantity divided by the number of shipments.

\section{[TABLE 2 HERE]}

Table 2 reports descriptive statistics for the U.S. and Spain. For both countries eight importers are selected that are relatively important trading partners; four with low and four with high per-shipment costs to import. A typical export shipment is worth around $\$ 14,500$ in the US and $\$ 13,200$ in Spain. ${ }^{3}$ Shipment sizes for selected individual destinations range between $\$ 9,700$ (Spain to Japan) and $\$ 29,250$ (US to China). These differences may depend on several factors, such as the nature of the product or the transport mode, which we will account for in the regression analysis.

\footnotetext{
${ }^{3}$ We obtain the median shipment value from the most disaggregated data with more than 3 millions of entries for both exporters, where we use the same threshold value to drop lowvalue shipments in both databases. We do this to keep the U.S. and Spanish data comparable as the U.S. Census has a reporting threshold of $\$ 2,500$. Spanish Customs have no reporting threshold. Our results are similar if we include all Spanish transactions.
} 
Trade transactions for a given product to a given destination show strong signs of lumpiness. If a product is exported to a given destination in a given month, then it is shipped typically only one or two times within the month. The strong US-Canada trade relationship is an exception, with four shipments each month. Trade is positive only in few months of the year. Both the U.S. and Spain ship a given product to a given destination in only 2 months within the year. These figures are comparable to those reported by Alessandria, Kaboski and Midrigan (2010) for monthly U.S. imports during 1990-2005. These authors also demonstrate that lumpiness is not driven by seasonality and that it is pervasive across different types of traded goods.

\section{Evidence on per-shipment costs and the margins of trade}

We want to see how the frequency and the size of shipments, two margins of trade, vary with the level of our per-shipment cost measures. We estimate gravity-like regressions on the different margins. Because physical product characteristics and transportation technology are likely important determinants the size and frequency of shipments, we include separate fixed effects for each mode of transportation with each product category.

We create two datasets, one for U.S. exports to 172 destinations, and one for Spanish exports to 144 non-EU destinations. ${ }^{4}$ Both datasets are using 2009 data. The unit of observation is a given product category shipping to a country of destination by a given mode

\footnotetext{
${ }^{4}$ We exclude EU destinations from the Spanish sample, because the per-shipment cost indicators are not relevant for the common EU market.
} 
of transport. Modes of transport are air, sea and ground.

We decompose the value of annual exports, $X$, of product $g$ by transport mode $m$ to country $j$ as the product of the number of shipments, $N$, and the average shipments value, $V$

$$
X_{j g m} \equiv N_{j g m} \cdot V_{j g m}
$$

The number of shipments, in turn, can be decomposed as the product of the number of months in the year with nonzero trade and the average number of shipments per month with trade, $N \equiv H \cdot N_{H}$. Similarly, the average shipment value is the average physical shipment size (in kilograms ${ }^{5}$ ) times the average price per kilogram, $V \equiv Q \cdot P$. Hence,

$$
X_{j g m} \equiv H_{j g m} \cdot N_{H, j g m} \cdot Q_{j g m} \cdot P_{j g m}
$$

We regress the margins from decompositions (1) and (2) on the per-shipment cost indicators, standard gravity variables and product-mode fixed effects. The regression equation is then

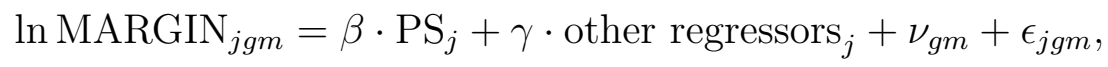

where MARGIN is either of $X, N, V, H, N_{H}, Q$, or $P$. Notice that, because the decompositions are an identity, the estimates of each coefficient from the margin regressions should sum up to the estimate in the total export regression.

\footnotetext{
${ }^{5}$ To have a unique quantity measure, we restrict the U.S. sample to those observations where quantity is reported in kilograms. Since weight in kilograms is reported for all air- or ocean-transported shipments, we need to exclude only part of the ground-transported trade, overall $4.4 \%$ of the U.S. sample.
} 
The destination-specific per-shipment cost variable is $\mathrm{PS}_{j}$, which is either the time cost or the natural logarithm of the monetary cost indicator from the Doing Business survey conducted in 2009. The other regressors are the natural logarithms of GDP, GDP per capita and geographical distance, as well as dummies for being landlocked, island, having Free Trade Agreement, common language and colonial history with the U.S. or Spain. The $\nu_{g m}$ are product-mode fixed effects and $\epsilon_{j g m}$ is the error term. ${ }^{6}$

Tables 3 and 4 report the regression estimates for decomposition (1) for the U.S. and Spain, respectively. On both samples we find that higher per-shipment trade barriers, both time and monetary, correspond to less frequent shipments and to larger shipment value. Meanwhile, total exports is affected to a lesser extent, if at all, by per-shipment costs.

The coefficients in Table 3 read as follows. U.S. exports of a given product shipped by a given transport mode in 2009 were, on average, $0.1 \%$ smaller to destinations where trading time was one day longer than in the average destination. This number is comprised of $0.4 \%$ fewer shipments and $0.3 \%$ larger average shipment value. Regarding monetary costs, a destination with one per cent higher-than-average costs received from the US within-productmode around $23 \%$ less shipments, while the shipment value was almost $5 \%$ higher.

\section{[TABLE 3 HERE]}

\section{[TABLE 4 HERE]}

We also find robust evidence for other regressors. More frequent and higher-value shipments are sent to larger economies, while countries that share an official language with the exporter receive more frequent and lower-value shipments.

\footnotetext{
${ }^{6}$ We do not account for zeros in trade and, hence, adjustment at the product (or transport mode) extensive margin.
} 
The estimates for the margins of decomposition (2) are reported in Table 5, with estimates for other regressors omitted to save space. Both the number of months with trade and the average number of shipments per month tend to be significantly lower in destinations with higher per-shipment costs. This suggests that per-shipment costs are, at least partly, also responsible for the concentration of shipments in relatively few months of the year. Similarly, both the shipment weight and the product's per-unit price tend to be larger when per-shipment costs are high.

\section{[TABLE 5 HERE]}

The Doing Business data allows us to distinguish the costs of four trade procedures, listed in Table 1. Table 6 reports regression results with two procedural cost variables, one combining the first two (documentation and customs), the other the last two (port and transit) procedures. The documentation and customs procedures are clearly administrative type of trade barriers ("red tape") and most likely unrelated to the size of the shipment. The port and transit procedures involve moving and storing the cargo and, hence, their cost might increase with the shipment weight. In other words, they are not pure per-shipment costs, but can also involve a per-unit cost component.

The two procedural cost measures differ accordingly in their effect on the shipment weight and the price. When the documentation and the customs procedure are more burdensome (both in terms of time and monetary costs), shipments tend to be larger in physical size, while the price changes only marginally. The monetary costs of port handling and transit however clearly correlate with higher per unit product prices. This latter finding is in line with the "shipping the good apples out" hypothesis (Alchian and Allen, 1964).

[TABLE 6 HERE] 
Finally, we ask whether our findings vary across products. We use the Broad Economic Categories (BEC) classification to distinguish between seven types of products: food and beverages (in short, Food), industrial supplies (Industrial), capital goods and transport equipment (Capital), parts and accessories thereof (Parts), as well as durable, semi-durable and non-durable consumer goods. Regressions for decomposition (1) with interactions of per-shipment costs and product group dummies are shown in Table 7 .

\section{[TABLE 7 HERE]}

That shipments tend to be less frequent and larger in case of higher per-shipment costs seems to be quite pervasive across product groups. The coefficients on the shipment frequency margin are negative, those on the shipment value margin are positive, albeit not always significantly different from zero. Nevertheless, evidence looks stronger for some product groups than for others. These are industrial supplies and, for time costs, food and beverages and parts and accessories. As for consumer goods, evidence is somewhat stronger for less durable goods than for durables.

Trade in industrial supplies and parts and accessories make up a large part of intermediate goods trade that link internationally fragmented production stages. Our tentative explanation for the strong evidence found here is that the incidence of per-shipment costs is high on fragmented production processes, which involve multiple cross-border shipping of intermediates. Fast delivery is also important when production stages have to be synchronized in a timely manner (Hummels, 2007). 


\section{Conclusion}

Trade barriers of a per-shipment nature are non-negligible costs to the trading firm. Firms can economize on them by sending fewer but larger shipments to destinations where these costs are high. Such a firm response can partly explain the lumpiness of trade transactions, which has recently been documented in the literature. Exploiting the substantial variation in per-shipment trade barriers by destination country, this paper provided empirical evidence using disaggregated U.S. and Spanish export data on the positive association between pershipment costs and trade lumpiness.

\section{References}

[1] Armen Albert Alchian and William Richard Allen, 1964. University Economics, Wadsworth Publishing Company, Belmont, CA.

[2] George Alessandria, Joseph Kaboski and Virgiliu Midrigan, 2010. "Inventories, Lumpy Trade, and Large Devaluations," American Economic Review, 100(5), pp. 2304-39. December.

[3] Roc Armenter and Miklós Koren, forthcoming. "The Balls-and-Bins Model of Trade," American Economic Review.

[4] David Hummels, 2007. "Transportation Costs and International Trade in the Second Era of Globalization," Journal of Economic Perspectives, 21(3), pp. 131-154. Summer. 
[5] David Hummels and Alexandre Skiba, 2004. "Shipping the Good Apples out? An Empirical Confirmation of the Alchian-Allen Conjecture," Journal of Political Economy, 112(6), pp. 1384-1402. December.

[6] Alfonso Irarrazabal, Andreas Moxnes and Luca David Opromolla, 2010. "The Tip of the Iceberg: Modeling Trade Costs and Implications for Intra-industry Reallocation," CEPR Discussion Paper No. DP7685. February.

[7] Andreas Kropf and Philip Sauré, forthcoming, "Fixed Costs per Shipment," Journal of International Economics. 
Tables 
Table 1: Time and monetary costs of four import procedures

\begin{tabular}{l|cc|cc}
\hline \hline & \multicolumn{2}{|c|}{ Time cost } & \multicolumn{2}{c}{ Monetary cost } \\
Procedure & Mean & CV & Mean & CV \\
\hline Document preparation & 13.8 & 0.78 & $\$ 307$ & 0.62 \\
Customs clearance and inspection & 3.7 & 0.74 & $\$ 207$ & 0.99 \\
Port and terminal handling & 4.7 & 0.77 & $\$ 318$ & 0.55 \\
Transit from port to destination & 4.6 & 1.56 & $\$ 772$ & 1.08 \\
\hline Total & 26.8 & 0.71 & $\$ 1,604$ & 0.63 \\
\hline Note: Based on Doing Business survey from 2009. Time costs are \\
in days, monetary costs in US dollars. Statistics for 179 countries. \\
CV is the coefficient of variation (standard deviation divided by the \\
mean).
\end{tabular}


Table 2: Lumpiness of exports

\begin{tabular}{|c|c|c|c|}
\hline \multicolumn{2}{|c|}{ median } & how many times & \multirow{2}{*}{$\begin{array}{c}\text { number of } \\
\text { months in year }\end{array}$} \\
\hline & shipment & good shipped & \\
\hline & value (US\$) & in a month & good shipped \\
\hline \multicolumn{4}{|c|}{ Exporter is U.S. } \\
\hline \multicolumn{4}{|c|}{ Selected low per-shipment cost importers } \\
\hline Canada & $\$ 13,940$ & 4.4 & 12 \\
\hline Germany & $\$ 13,769$ & 1.3 & 4 \\
\hline Israel & $\$ 13,230$ & 1.0 & 2 \\
\hline Singapore & $\$ 13,341$ & 1.3 & 4 \\
\hline \multicolumn{4}{|c|}{ Selected high per-shipment cost importers } \\
\hline Chile & $\$ 13,767$ & 1.0 & 3 \\
\hline China & $\$ 29,250$ & 1.5 & 4 \\
\hline Russia & $\$ 28,157$ & 1.0 & 2 \\
\hline Venezuela & $\$ 24,011$ & 1.0 & 3 \\
\hline All importers & $\$ 14,467$ & 1.0 & 2 \\
\hline
\end{tabular}

Continued on next page... 
Table 2 continued from previous page...

\begin{tabular}{|c|c|c|c|}
\hline \multicolumn{2}{|c|}{ median } & how many times & \multirow{2}{*}{$\begin{array}{c}\text { number of } \\
\text { months in year }\end{array}$} \\
\hline & shipment & good shipped & \\
\hline & value (US\$) & in a month & good shipped \\
\hline \multicolumn{4}{|c|}{ Exporter is Spain } \\
\hline \multicolumn{4}{|c|}{ Selected low per-shipment cost importers } \\
\hline France & $\$ 14,203$ & 1.5 & 9 \\
\hline Germany & $\$ 14,217$ & 1.3 & 7 \\
\hline Japan & $\$ 9,674$ & 1.0 & 2 \\
\hline USA & $\$ 15,592$ & 1.0 & 3 \\
\hline \multicolumn{4}{|c|}{ Selected high per-shipment cost importers } \\
\hline Algeria & $\$ 15,894$ & 1.0 & 2 \\
\hline China & $\$ 19,442$ & 1.0 & 2 \\
\hline Russia & $\$ 12,263$ & 1.0 & 2 \\
\hline South Africa & $\$ 11,725$ & 1.0 & 2 \\
\hline All importers & $\$ 13,234$ & 1.0 & 2 \\
\hline
\end{tabular}


Table 2 continued from previous page...

Note: U.S. exports to 172 importers in 2009 with 8,602 ten-digit product categories $(N=3,426,039)$ and Spanish exports to 144 non-EU and 25 EU importers in 2009 in 8,381 eight-digit product lines $(N=3,019,277)$. For U.S. shipment value is the frequency-weighted median of data points at the highest-level of disaggregation. For Spain shipment value is the median of individual shipments, converted to U.S. dollars with monthly average USD/EUR exchange rates. Shipment frequency statistics are for the median product. Trade in fuels and low-value shipments (less than $\$ 2,500$ for U.S. and less than EUR 2,000 for Spain) are excluded. 


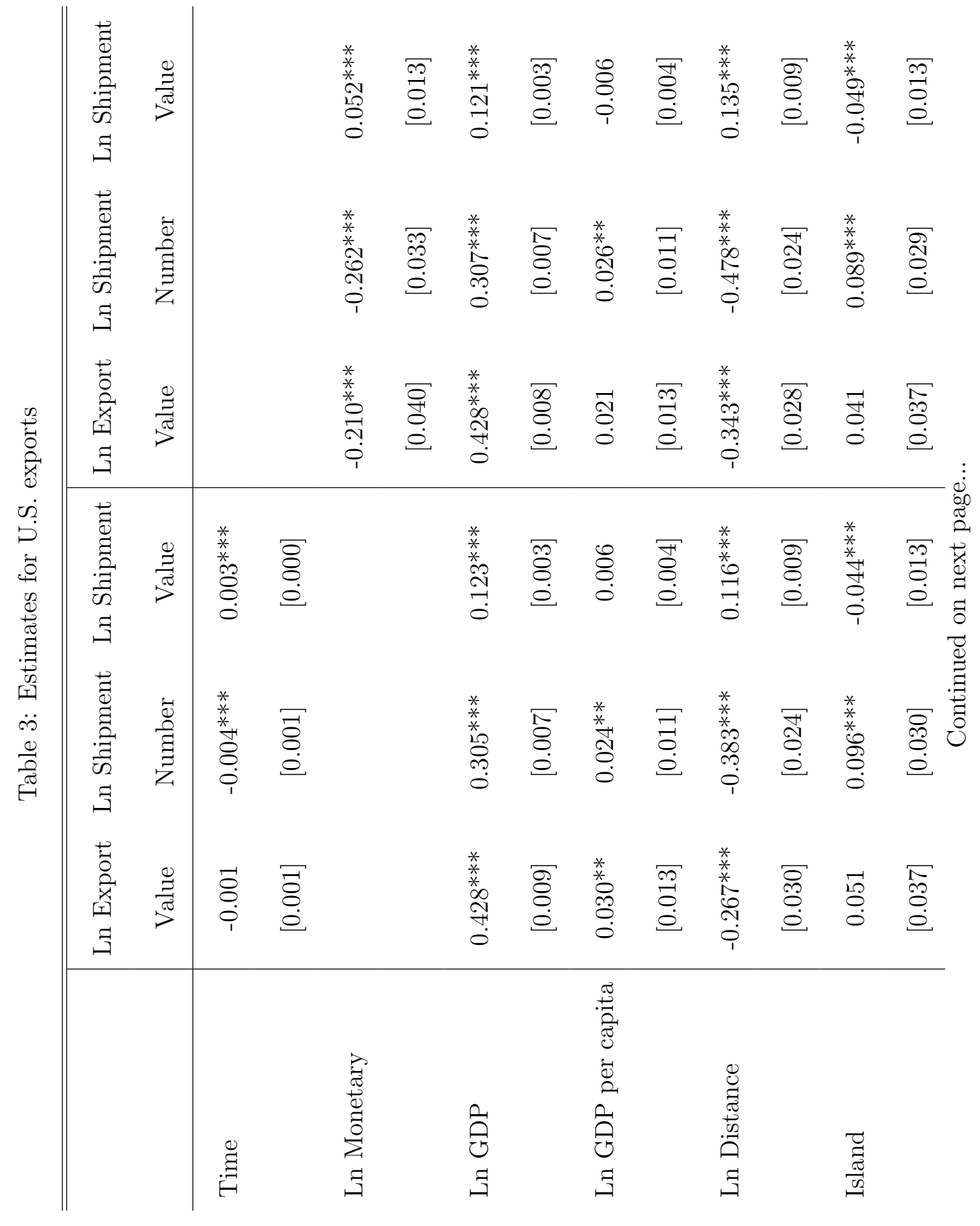




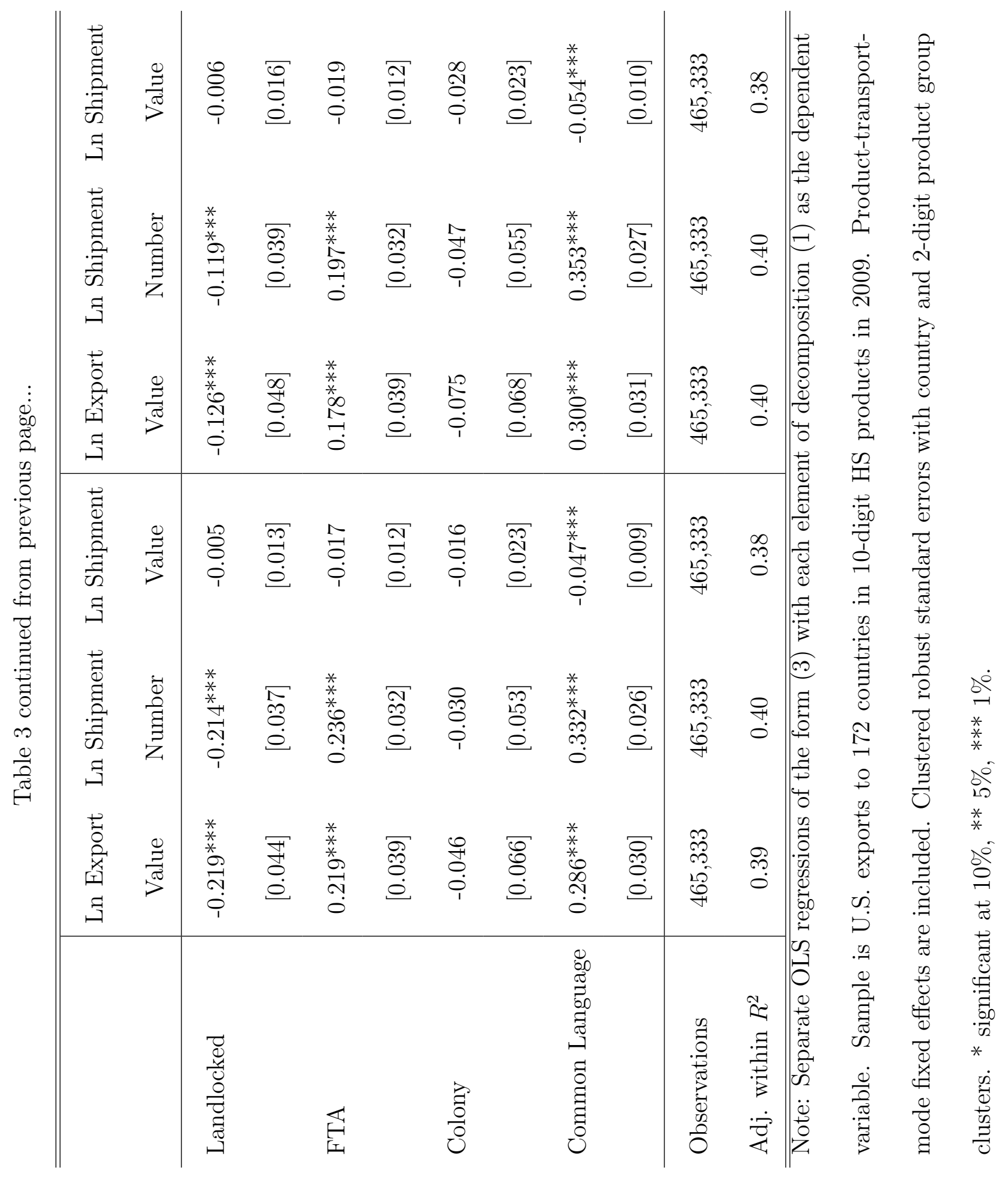




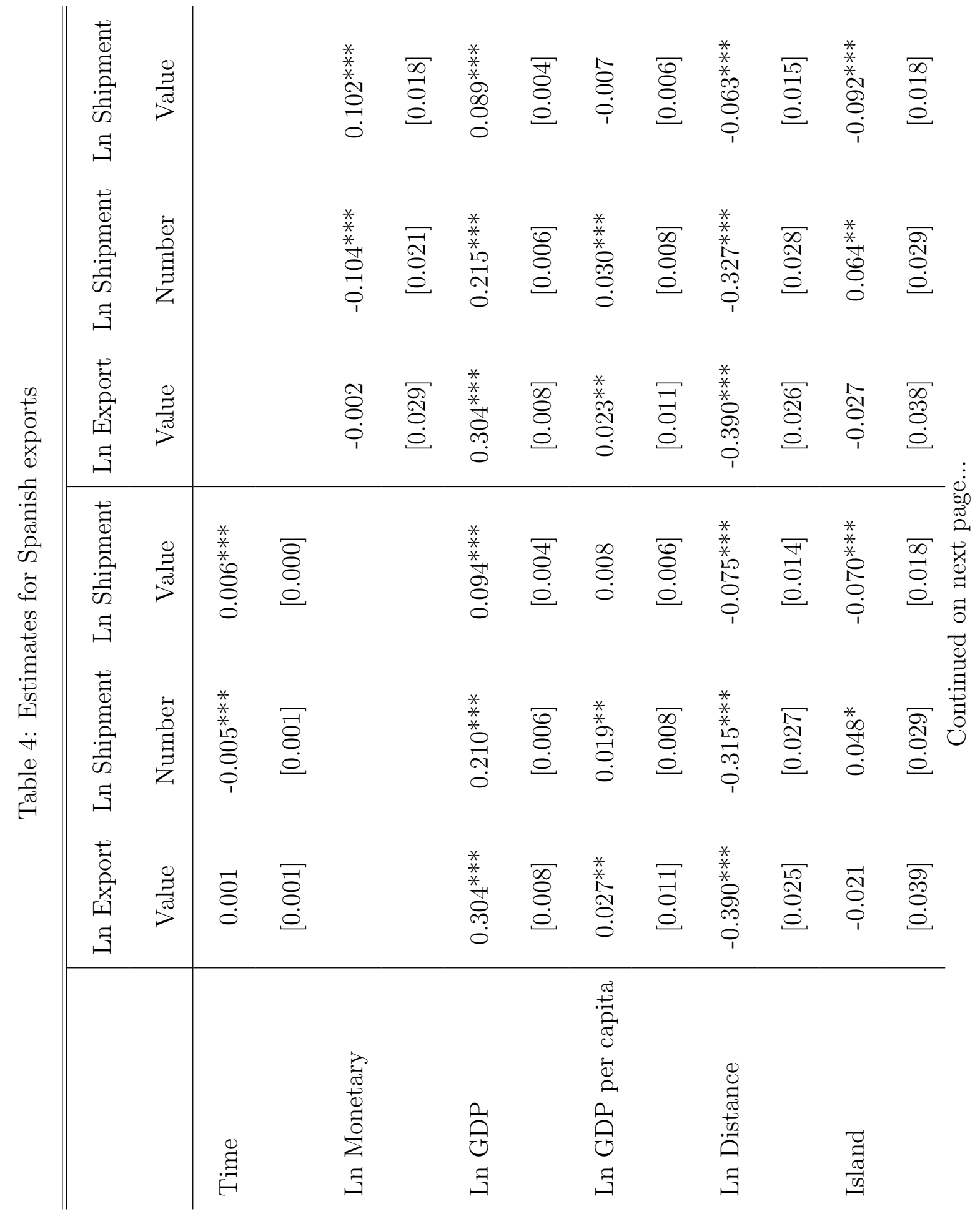




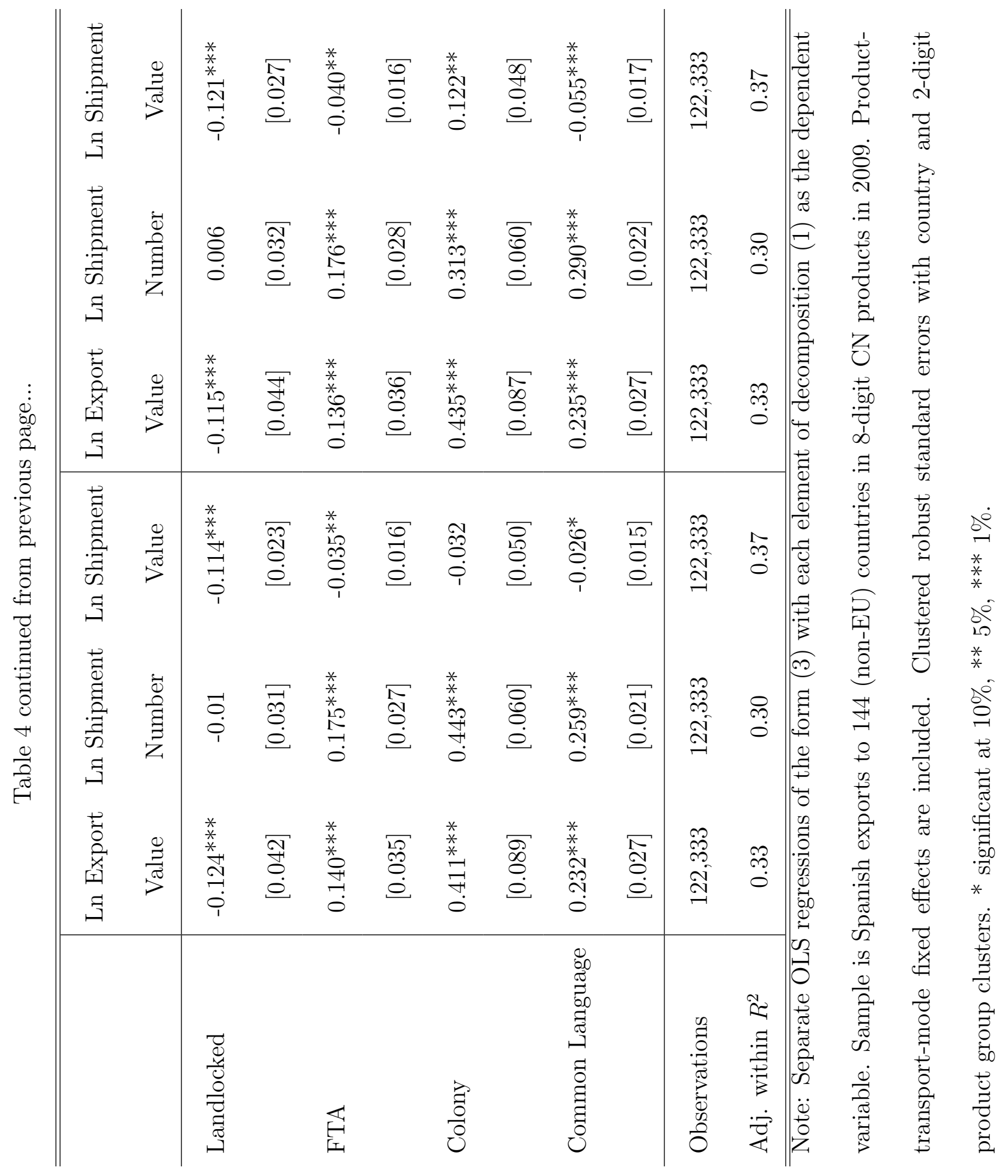


Table 5: Detailed decomposition regressions

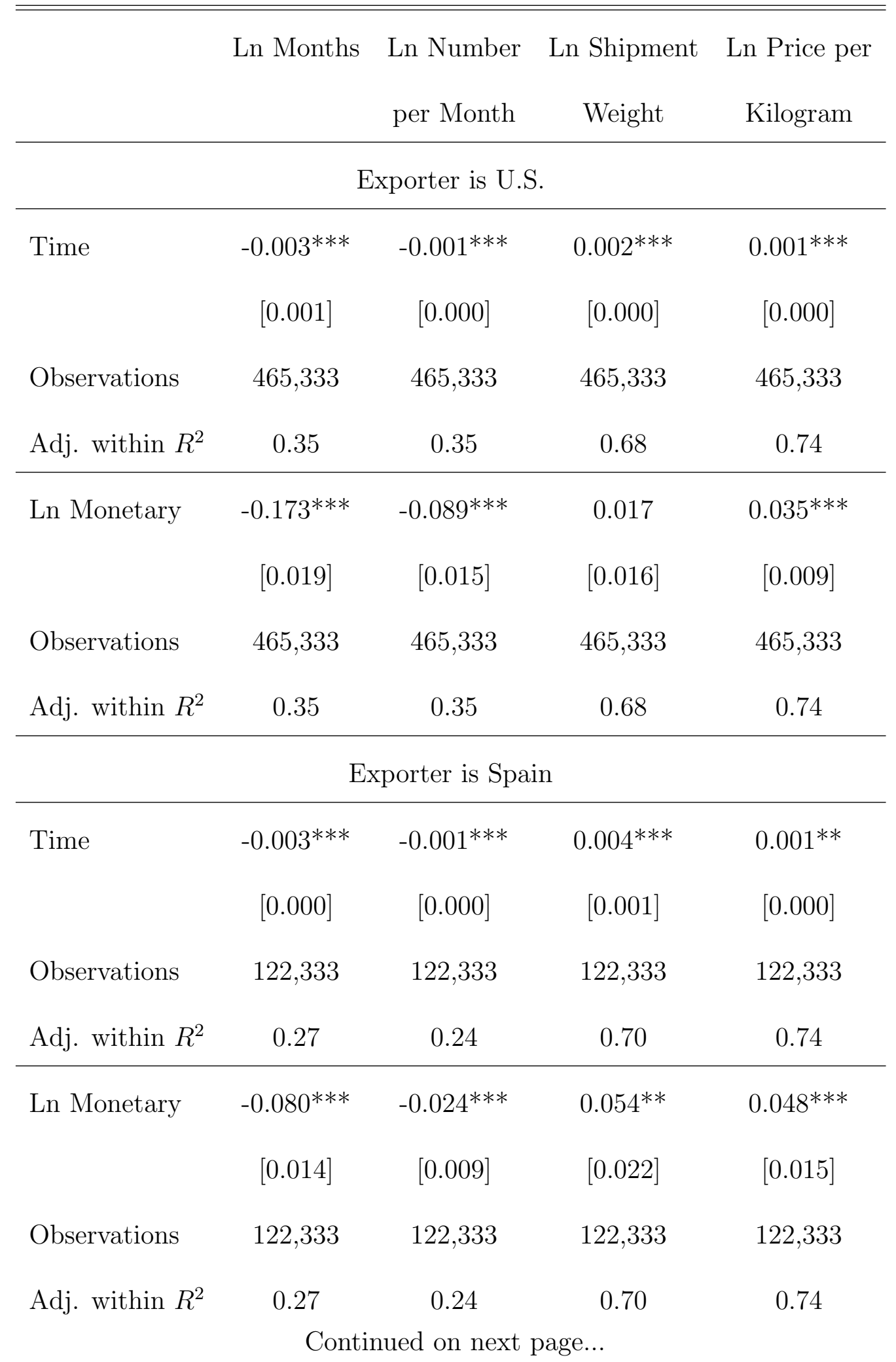


Table 5 continued from previous page...

Note: Separate OLS regressions of the form (3) with each element of decomposition (2) as the dependent variable. Sample is U.S. (Spanish) exports to 172 (144) countries in 10-digit HS (8-digit CN) products in 2009. Product-transport-mode fixed effects and other regressors (ln GDP, ln GDP per capita, ln distance, dummies for island, landlocked, FTA, colonial relationship, common language) are included but not reported. Clustered robust standard errors with country and 2-digit product group clusters. ${ }^{*}$ significant at $10 \%,{ }^{*} * 5 \%,{ }^{* * *} 1 \%$. 
Table 6: Regressions with two procedural costs

\begin{tabular}{lcccc}
\hline \hline & Ln Months & Ln Number & Ln Shipment & Ln Price per \\
& & per Month & Weight & Kilogram \\
\hline & \multicolumn{1}{c}{ Exporter is U.S. } & & \\
\hline Time doc.\&customs & $-0.003^{* * *}$ & $-0.002^{* * *}$ & $0.003^{* * *}$ & $0.001^{* *}$ \\
& {$[0.001]$} & {$[0.001]$} & {$[0.001]$} & {$[0.001]$} \\
Time port\&transit & $-0.004^{* * *}$ & 0.000 & -0.002 & 0.000 \\
& {$[0.002]$} & {$[0.001]$} & {$[0.002]$} & {$[0.001]$} \\
Observations & 465,333 & 465,333 & 465,333 & 465,333 \\
Adj. within $R^{2}$ & 0.35 & 0.35 & 0.68 & 0.74 \\
\hline Ln Monetary doc.\&customs & $-0.098^{* * *}$ & $-0.073^{* * *}$ & 0.012 & -0.003 \\
& {$[0.014]$} & {$[0.012]$} & {$[0.013]$} & {$[0.008]$} \\
Ln Monetary port\&transit & $-0.073^{* * *}$ & $-0.025^{*}$ & 0.006 & $0.035^{* * *}$ \\
& {$[0.017]$} & {$[0.014]$} & {$[0.016]$} & {$[0.010]$} \\
Observations & 465,333 & 465,333 & 465,333 & 465,333 \\
\hline & 0.35 & 0.35 & 0.68 & 0.74 \\
\hline
\end{tabular}

Continued on next page... 
Table 6 continued from previous page...

\begin{tabular}{|c|c|c|c|c|}
\hline & Ln Months & Ln Number & Ln Shipment & Ln Price per \\
\hline & & per Month & Weight & Kilogram \\
\hline \multicolumn{5}{|c|}{ Exporter is Spain } \\
\hline \multirow[t]{2}{*}{ Time doc.\&customs } & $-0.003^{* * *}$ & $-0.001^{* * *}$ & $0.004^{* * *}$ & 0.000 \\
\hline & {$[0.001]$} & {$[0.000]$} & {$[0.001]$} & {$[0.001]$} \\
\hline \multirow[t]{2}{*}{ Time port\&transit } & $-0.005^{* * *}$ & $-0.002^{*}$ & $0.004^{*}$ & 0.003 \\
\hline & {$[0.001]$} & {$[0.001]$} & {$[0.002]$} & {$[0.002]$} \\
\hline Observations & 122,333 & 122,333 & 122,333 & 122,333 \\
\hline Adj. within $R^{2}$ & 0.27 & 0.24 & 0.70 & 0.74 \\
\hline \multirow[t]{2}{*}{ Ln Monetary doc.\&customs } & $-0.021^{*}$ & 0.010 & $0.108^{* * *}$ & $-0.029 * *$ \\
\hline & {$[0.011]$} & {$[0.007]$} & {$[0.017]$} & {$[0.012]$} \\
\hline \multirow[t]{2}{*}{ Ln Monetary port\&transit } & $-0.055^{* * *}$ & $-0.029 * * *$ & -0.030 & $0.064^{* * *}$ \\
\hline & {$[0.012]$} & {$[0.008]$} & {$[0.019]$} & {$[0.012]$} \\
\hline Observations & 122,333 & 122,333 & 122,333 & 122,333 \\
\hline Adj. within $R^{2}$ & 0.27 & 0.24 & 0.70 & 0.74 \\
\hline \multicolumn{2}{|c|}{ (2) as the dependent variable. Sample is U.S. (Spanish) exports to 172 (144) coun- } & & & \\
\hline \multicolumn{5}{|c|}{ tries in 10-digit HS (8-digit CN) products in 2009. Product-transport-mode fixed } \\
\hline \multicolumn{5}{|c|}{ effects and other regressors (ln GDP, ln GDP per capita, ln distance, dummies for } \\
\hline \multicolumn{5}{|c|}{ island, landlocked, FTA, colonial relationship, common language) are included but } \\
\hline \multicolumn{5}{|c|}{ not reported. Clustered robust standard errors with country and 2-digit product } \\
\hline
\end{tabular}




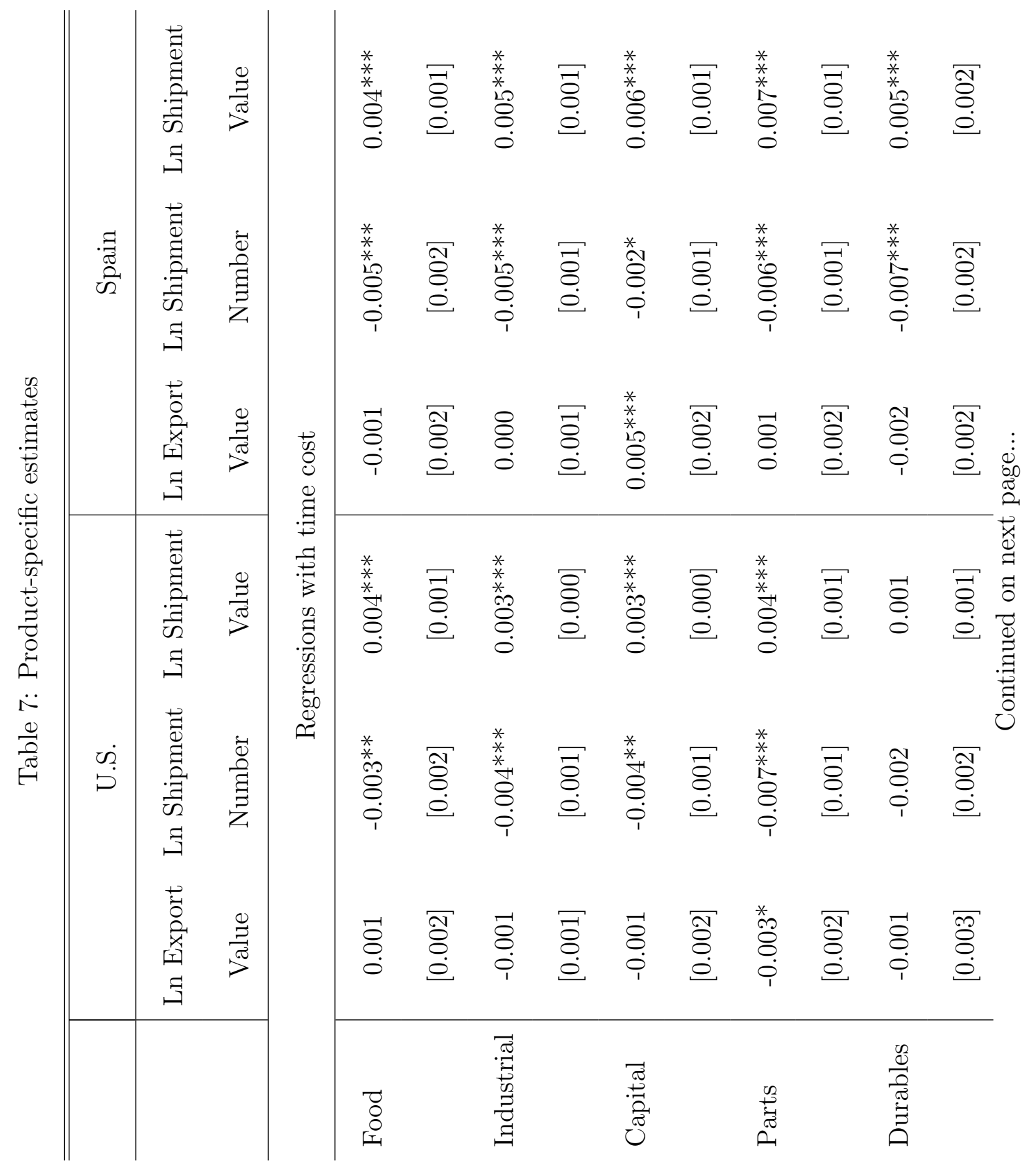




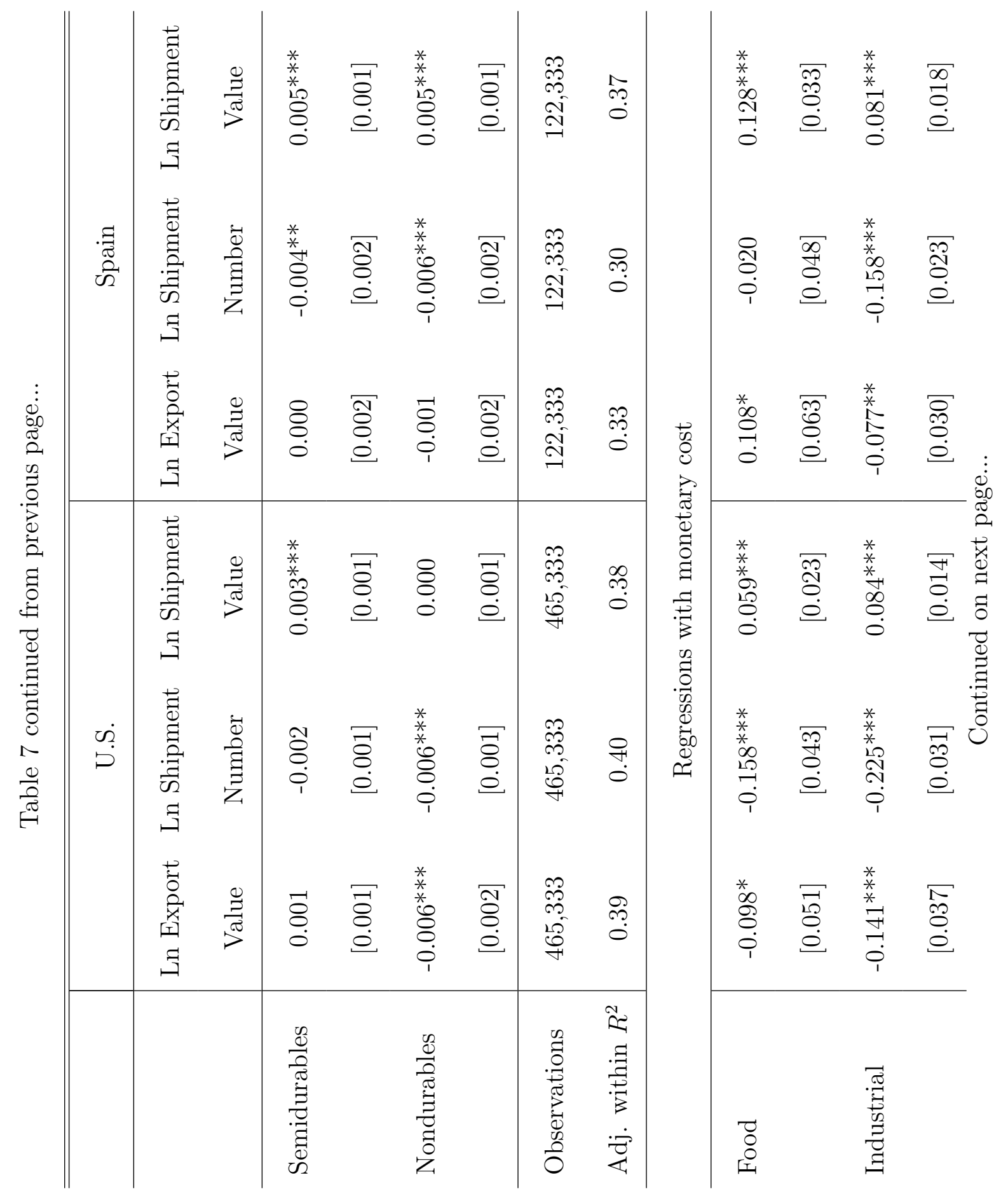




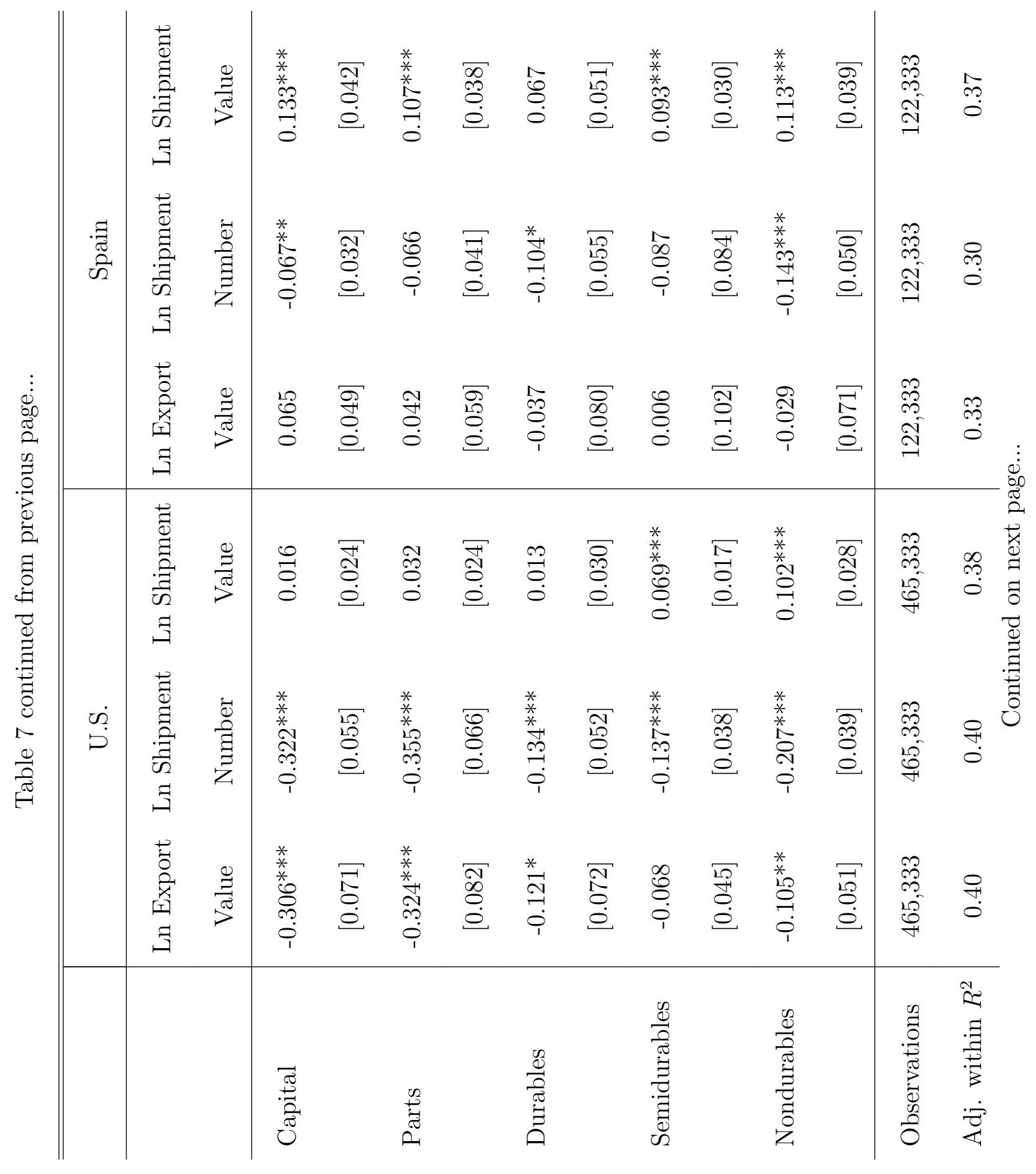




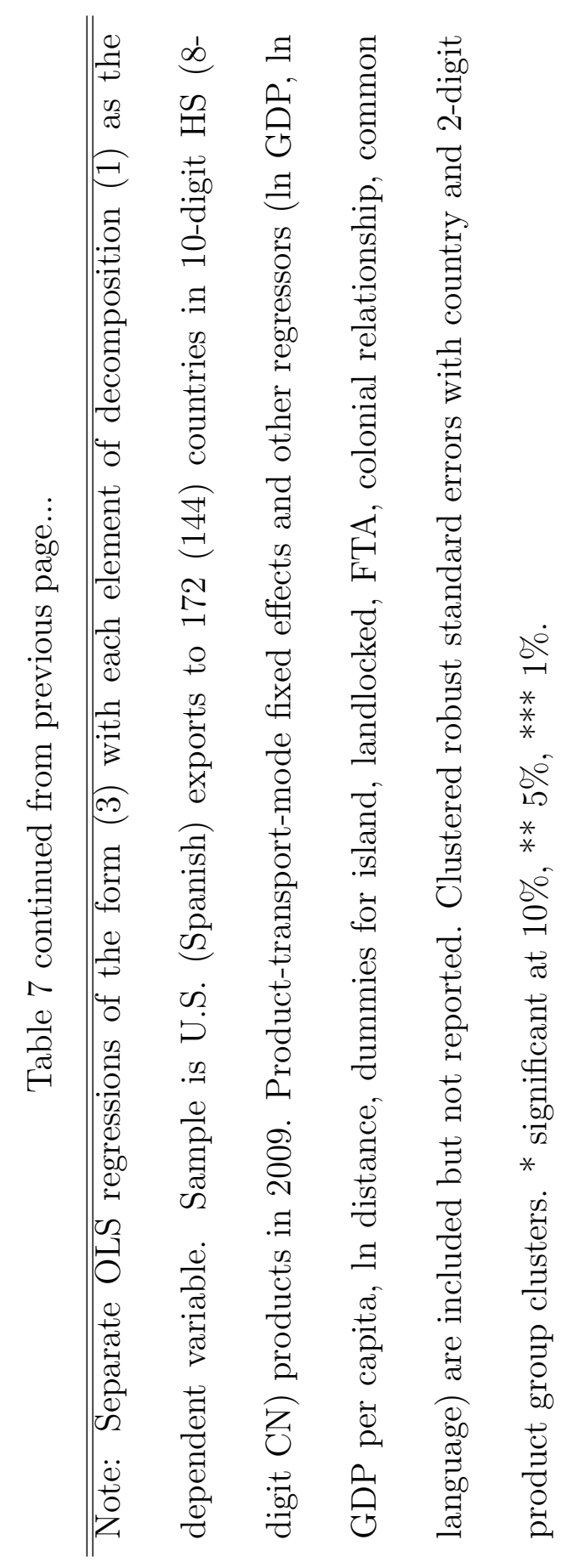

